\title{
9. OBS AIRGUN SEISMIC REFRACTION SURVEY NEAR SITES 441 AND 434 (J-1A), 438 AND 439 (J-12), AND PROPOSED SITE J-2B: LEGS 56 AND 57, DEEP SEA DRILLING PROJECT
}

\author{
Shozaburo Nagumo, Junzo Kasahara, and Sadayuki Koresawa, Earthquake Research Institute, \\ University of Tokyo, Tokyo, Japan
}

\begin{abstract}
Within the Japan Trench inner wall toe, near Sites 441 and 434, the $P$-wave refraction velocity is 2.6 to $2.8 \mathrm{~km} / \mathrm{s}$. The velocity of the oceanic layer $2 \mathrm{~B}$, which underlies the inner wall toe, is $5.7 \mathrm{~km} / \mathrm{s}$. This high velocity might be caused by either overburden pressure or by local dipping. Near Sites 438 and 439 , the $P$-wave velocity of the basement below the unconformity is $4.8 \mathrm{~km} / \mathrm{s}$, consistent with preTertiary rocks. At proposed Site J-2B, the Neogene layer of 2.75 $\mathrm{km} / \mathrm{s}$ is underlain by a high-velocity layer of $6.0 \mathrm{~km} / \mathrm{s}$. Near Sites 441 and 434, using $P$ to $S$ as well as $S$ to $P$ converted phases, velocity ratio, $\bar{V}_{p} / \bar{V}_{s}$, and poisson's ratio, $\sigma$, within the inner wall toe are $\bar{V}_{p} / \bar{V}_{j}=2.53$ and $\sigma=0.41\left(\bar{V}_{p}=\right.$ average $P$-wave velocity; $\bar{V}_{s}=$ average $S$-wave velocity). The average $S$-wave velocity within the toe is $0.91 \mathrm{~km} / \mathrm{s}$ for average $P$-wave velocity $2.3 \mathrm{~km} / \mathrm{s}$.
\end{abstract}

\section{INTRODUCTION}

As a site survey, an ocean bottom seismograph (OBS) airgun seismic refraction survey was conducted at proposed drill sites J-1A (near Sites 441 and 434), J-2B, and J-12 (near Sites 438 and 439) in June 1977 by HakuhoMaru of the Ocean Research Institute, University of Tokyo (Table 1).

Shooting lines were taken parallel to the trench axis (Figure 1) so as to minimize topographic variation. The ship speed was $5 \mathrm{kt}$, and shot interval was $30 \mathrm{~s}$. The airgun capacity was 300 in. $^{3}$ with pressure 80 to 90 $\mathrm{kg} / \mathrm{cm}^{2}$. OBS was deployed by an anchored buoy system that assured accurate position. The recording instruments are composed of geophones $\left(f_{0}=1-\mathrm{Hz}\right.$ vertical component, $\mathrm{f}_{0}=4.5-\mathrm{Hz}$ horizontal component), amplifiers (80-90 dB.), DR tape recorder, and time-coded crystal clock (for instruments and method, see Nagumo and Kasahara, 1976).

Travel time record sections were obtained from the field tape by digital processing. Travel time record sections for J-1A (near Sites 441 and 434), J-12 (near Sites 438 and 439), and J-2B are shown in Figures 2, 3, and 4, respectively. Velocity structures are shown in Table 2 as well as in Figure 5.

TABLE 1

Data of OBS Sites

\begin{tabular}{|c|c|c|c|c|c|}
\hline \multirow[b]{2}{*}{ Station } & \multicolumn{2}{|c|}{ Position } & \multirow{2}{*}{$\begin{array}{l}\text { Depth } \\
\text { (m) }\end{array}$} & \multirow{2}{*}{$\begin{array}{l}\text { Observation } \\
\text { Period }\end{array}$} & \multirow[b]{2}{*}{ Recorder } \\
\hline & Latitude & Longitude & & & \\
\hline$J-1 A$ & $39^{\circ} 45.7^{\prime} \mathrm{N}$ & $144^{\circ} 05.1^{\prime} \mathrm{E}$ & 5480 & $\begin{array}{l}\text { June } 3-4 \text {, } \\
1977\end{array}$ & $\begin{array}{l}\text { DR-915 } \\
\text { and G-A }\end{array}$ \\
\hline$J-12$ & $40^{\circ} 38.7^{\prime} \mathrm{N}$ & $143^{\circ} 18.5^{\prime} \mathrm{E}$ & 1620 & $\begin{array}{l}\text { June 1-2, } \\
1977\end{array}$ & $\begin{array}{l}\text { G-B and } \\
\text { NK-2 }\end{array}$ \\
\hline$J-2 B$ & $39^{\circ} 46.0^{\prime} \mathrm{N}$ & $143^{\circ} 21.1 \mathrm{E}$ & 2155 & $\begin{array}{l}\text { May 28-29, } \\
1977\end{array}$ & $\begin{array}{l}\text { DR-915 } \\
\text { and NK-1 }\end{array}$ \\
\hline
\end{tabular}

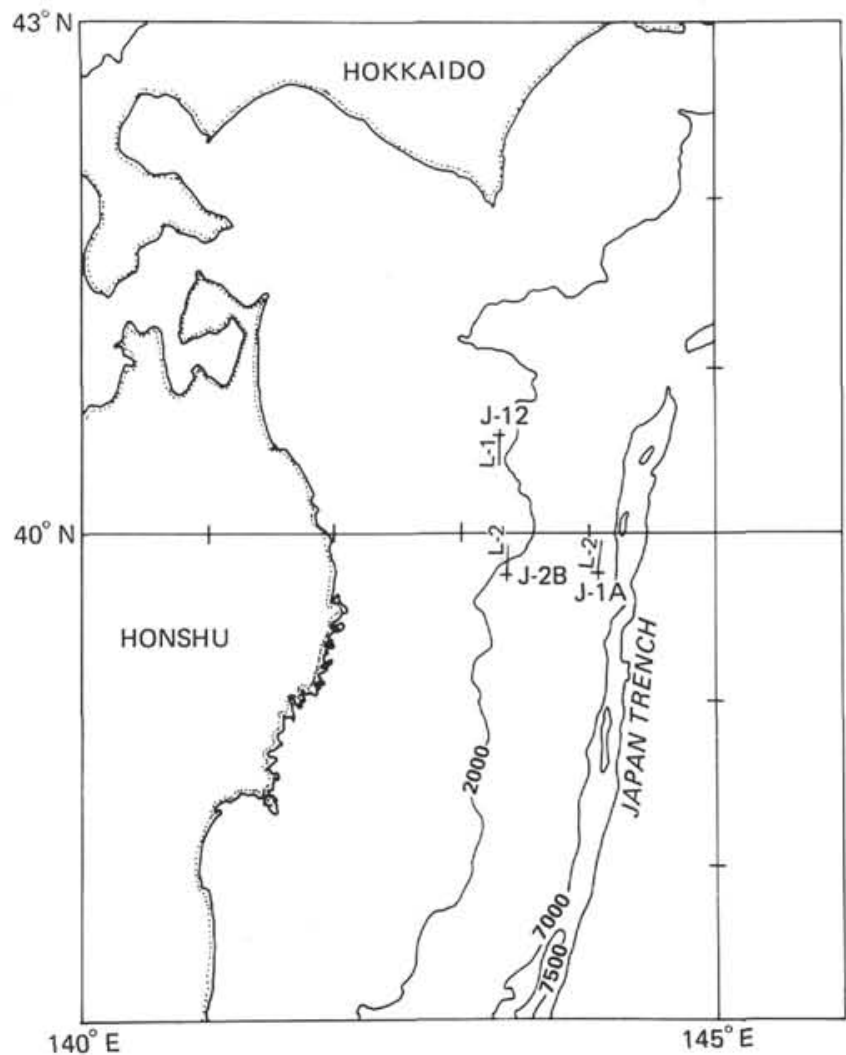

Figure 1. OBS-airgun refraction survey sites: $J-1 A$ (near Sites 441 and 434), J-12 (near Sites 438 and 439), and J-2B (not drilled). Small solid line running parallel to the trench axis at each site shows survey line.

\section{Sites 441 and 434 (J-1A)}

Three refracted waves are clearly seen in Figure 2. Their apparent velocities are $2.62 \mathrm{~km} / \mathrm{s}, 2.81 \mathrm{~km} / \mathrm{s}$, and 


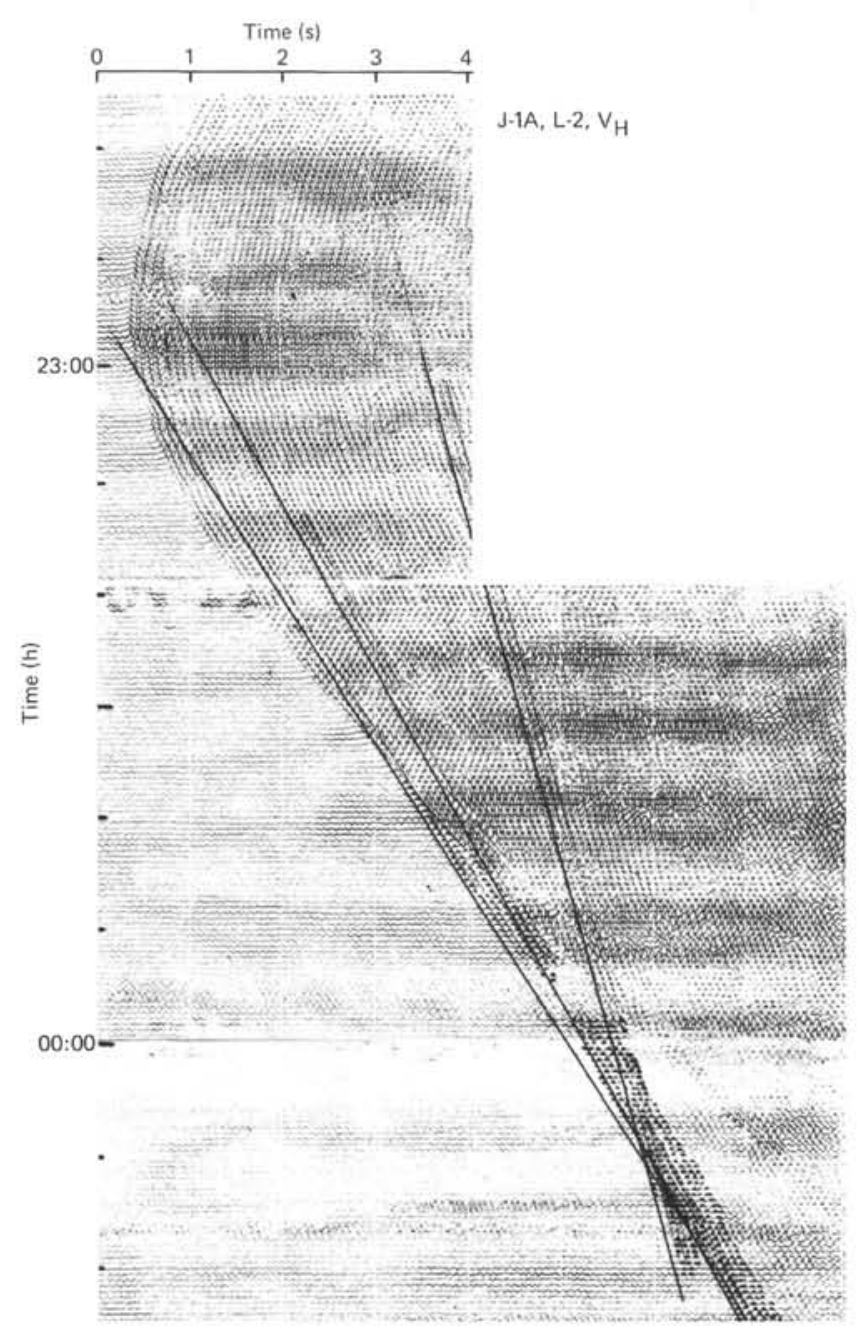

Figure 2. Record section for OBS airgun refraction survey at Site J-1A (near Sites 441 and 434). Ship speed: $5 \mathrm{kt}$. Travel times are shifted by $+3.431 \mathrm{~s}$. Solid straight lines fitted to P-wave refraction arrivals for 2.62, 2.81, and $5.73 \mathrm{~km} / \mathrm{s}$, respectively. Seismic traces are $30 \mathrm{~s}$ spacing.

$5.73 \mathrm{~km} / \mathrm{s}$, respectively. The straight line fitting gives travel times $T_{1}, T_{2}$, and $T_{3}$ as $T_{1}=\Delta / 2.62+3.61(\mathrm{~s})$, $\mathrm{T}_{2}=\Delta / 2.81+4.01(\mathrm{~s})$, and $\mathrm{T}_{3}=\Delta / 5.73+6.62(\mathrm{~s})(\Delta$ $=$ distance in $\mathrm{km}$ ).

Because of unreversed shooting in rather rough topography, it is difficult to derive true seismic velocity. However, to obtain an approximate idea about the depth of each layer, we performed a calculation, assuming a constant velocity, discrete-layered model. The results are shown in Table 2 . The velocity $1.8 \mathrm{~km} / \mathrm{s}$ of the top sediment layer was assumed based on the multichannel seismic survey in this region.

The $2.8 \mathrm{~km} / \mathrm{s}$ layer corresponds to the lower portion of the slope mass as seen in the multichannel seismic profile. The base of the $2.8 \mathrm{~km} / \mathrm{s}$ layer is $9.83 \mathrm{~km}$ below sea surface, and the thickness of the slope mass is about $4.3 \mathrm{~km}$.

The $5.7 \mathrm{~km} / \mathrm{s}$ layer corresponds to the oceanic acoustic basement, which subducts under the slope mass from

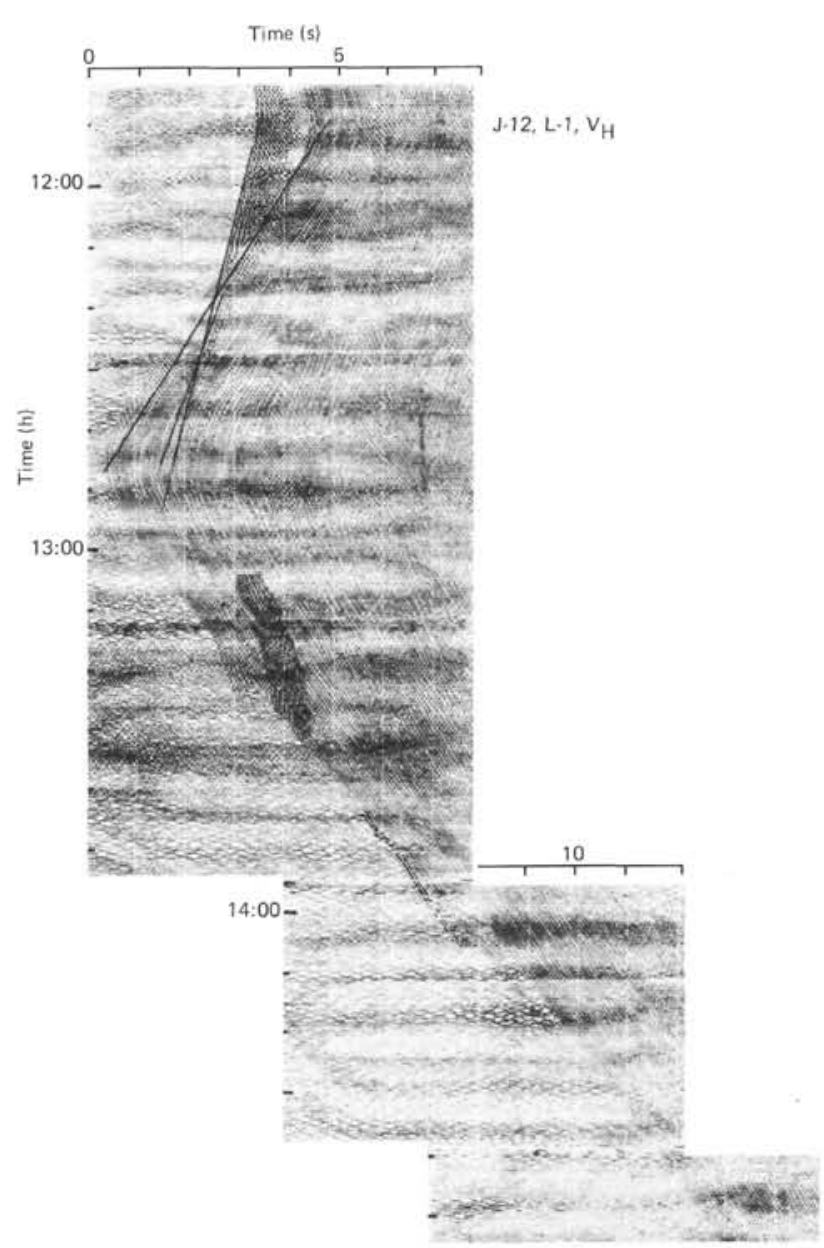

Figure 3. Record section for OBS airgun refraction survey at Site J-12 (near Sites 438 and 439). Ship speed: $5 \mathrm{kt}$. Travel times are shifted by $+0.693 \mathrm{~s}$. Solid straight lines fitted to $\mathrm{P}$-wave refraction arrivals for $2.09,3.25$, and $4.84 \mathrm{~km} / \mathrm{s}$, respectively.

the oceanic side. The velocity $5.7 \mathrm{~km} / \mathrm{s}$ is higher than the average velocity of layer $2 \mathrm{~B}(4.5-5.0 \mathrm{~km} / \mathrm{s}$, Houtz and Ewing, 1976). Such high velocity is probably caused either by pressure effect due to the overriding trench slope mass, which is about $4.3 \mathrm{~km}$ thick at the site, or by local dipping effect of the refractor.

\section{Sites 438 and $439(\mathrm{~J}-12)$}

Top layer $1.8 \mathrm{~km} / \mathrm{s}$ was assumed. The $2.1 \mathrm{~km} / \mathrm{s}$ layer may correspond to Neogene formation. The thin $(3.25$ $\mathrm{km} / \mathrm{s}$ ) layer and its underlying $4.8 \mathrm{~km} / \mathrm{s}$ high-velocity layer may correspond to pre-Tertiary rocks, which lie below the unconformity drilled at Site 439 .

\section{Proposed Site J-2B}

Site J-2B is about $95 \mathrm{~km}$ south of Sites 438 and 439 . The velocity $2.75 \mathrm{~km} / \mathrm{s}$ corresponds to the sedimentary rocks of Miocene. There is a sharp velocity discontinuity between the $2.75 \mathrm{~km} / \mathrm{s}$ layer and the $6.0 \mathrm{~km} / \mathrm{s}$ layer. The velocity $6.0 \mathrm{~km} / \mathrm{s}$ is higher than that of sedimentary rocks. Though it is possible that such high velocity is due to local dipping effect of the refractor, it is also 


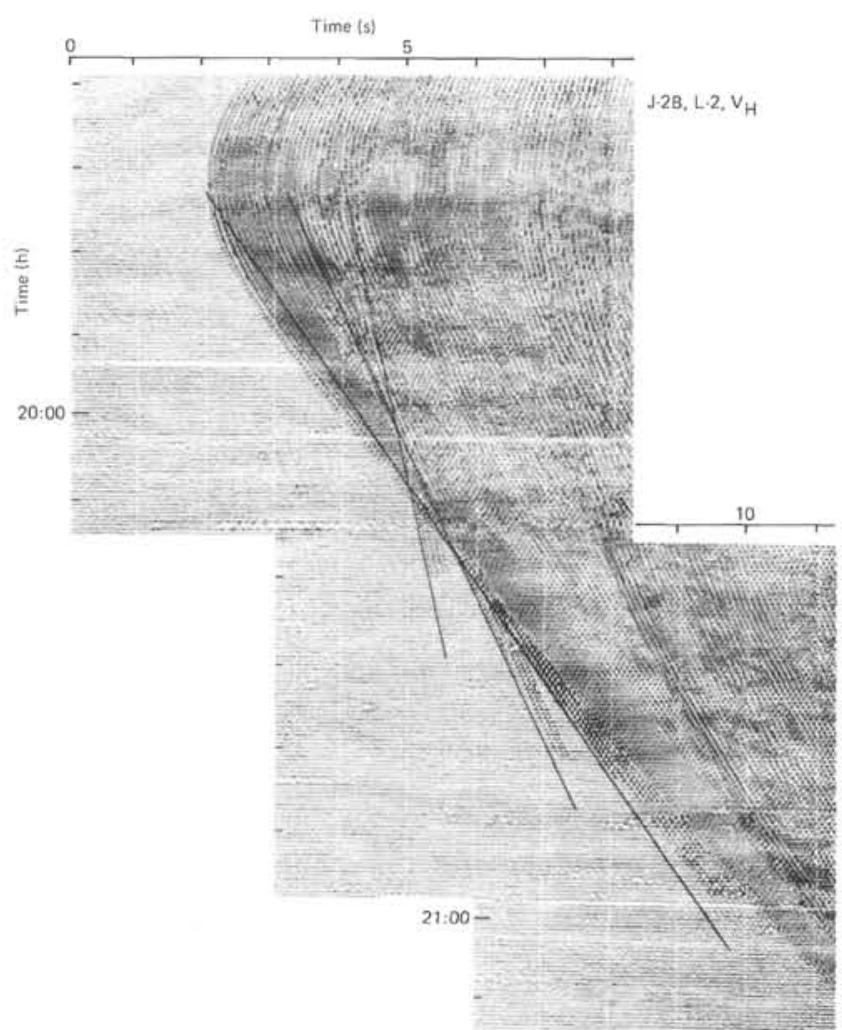

Figure 4. Record section for OBS airgun refraction survey at Site J-2B (not drilled). Ship speed: $5 \mathrm{kt}$. Travel times are shifted by -0.470 s. Solid straight lines fitted to $\mathrm{P}$-wave refraction arrivals for $1.92,2.75$, and $6.05 \mathrm{~km} / \mathrm{s}$, respectively.

TABLE 2

$P$-Wave Velocity Structure at Sites J-1A (near Sites 441 and 434), J-12 (near Sites 438 and 439 ), and J-2B (not drilled) Obtained by OBS Airgun Refraction Survey

\begin{tabular}{cccc}
\hline Layer & $\begin{array}{l}\text { Velocity } \\
(\mathrm{km} / \mathrm{s})\end{array}$ & $\begin{array}{c}\text { Intercept } \\
\text { Time }(\mathrm{s})\end{array}$ & $\begin{array}{c}\text { Thickness } \\
(\mathrm{km})\end{array}$ \\
\hline
\end{tabular}

\begin{tabular}{|c|c|c|c|}
\hline Layer & $(\mathrm{km} / \mathrm{s})$ & Time (s) & $(\mathrm{km})$ \\
\hline \multicolumn{4}{|c|}{ Site J-1A } \\
\hline 0 & 1.5 & - & 5.48 \\
\hline 1 & $1.8^{\mathrm{a}}$ & - & 0.67 \\
\hline 2 & 2.62 & 3.61 & 1.23 \\
\hline 3 & 2.81 & 4.01 & 2.45 \\
\hline 4 & 5.73 & 6.62 & - \\
\hline \multicolumn{4}{|c|}{ Site J-12 } \\
\hline 0 & 1.5 & - & 1.62 \\
\hline 1 & $1.8^{\mathrm{a}}$ & - & 0.39 \\
\hline 2 & 2.09 & 0.97 & 0.70 \\
\hline 3 & 3.25 & 1.83 & 0.15 \\
\hline 4 & 4.84 & 2.10 & - \\
\hline \multicolumn{4}{|c|}{ Site J-2B } \\
\hline 0 & 1.5 & - & 2.16 \\
\hline 1 & 1.92 & - & 1.72 \\
\hline 2 & 2.75 & 2.49 & 0.63 \\
\hline 3 & 6.05 & 3.50 & - \\
\hline
\end{tabular}

${ }^{\mathrm{a}}$ Assumed.

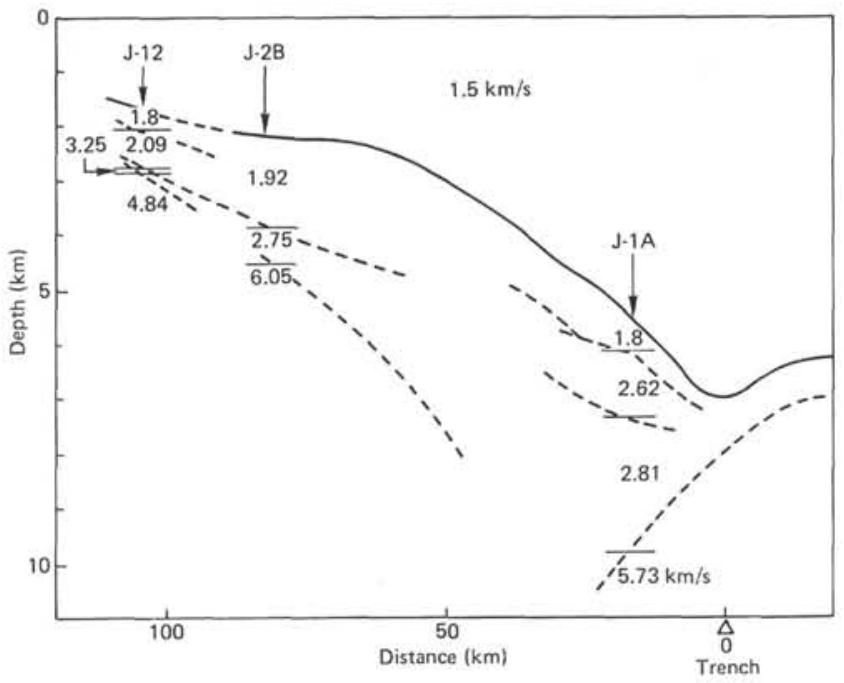

Figure 5. P-wave velocity profile across Japan Trench inner wall obtained by OBS airgun refraction survey in 1977.

possible that the high velocity is indicative of the presence of igneous rocks. If so, it might be evidence that "igneous roots" for the deposits, such as the dacitic conglomerate sampled at Site 439, may exist locally-that is, very near the trench slope break. Further study will be needed.

\section{$S$-Wave Velocity Measurement}

$S$-wave velocity as well as poisson's ratio within the inner wall toe is determined near Sites 441 and 434 (Nagumo et al., in press). During this OBS airgun refraction survey, the ocean bottom seismograph recorded many natural earthquakes. $P$ to $S(P S)$ and $S$ to $P(S P)$ conversion phases are clearly observed (Figure 6). The average delay time between $P$ and $P S$ converted phase and between $S$ and $S P$ converted phase is about $2.6 \mathrm{~s}$. Since the velocity contrast is very sharp at the interface between the trench slope mass and the subducting oceanic mass, it is thought that the conversion occurs efficiently.

Using both normal reflection time and conversion delay time, we have $\bar{V}_{p} / \bar{V}_{s}=2.53\left(\bar{V}_{p}=\right.$ average $P$-wave velocity; $\bar{V}_{S}=$ average $S$-wave velocity), and hence poisson's ratio $\sigma=0.41$. Since multichannel stacking velocity (Matsuzawa et al., in press) gives average $P$-wave velocity $\bar{V}_{p}=2.3 \mathrm{~km} / \mathrm{s}$ in this region, we have $\bar{V}_{s}=0.91 \mathrm{~km} / \mathrm{s}$. The large poisson's ratio $(\sigma=$ 0.41 ) implies that the medium within the toe is almost in a plastic state, with very small rigidity.

\section{ACKNOWLEDGMENTS}

The writers wish to express their hearty thanks to the chief scientist of the Hakuho-Maru KH-77-1 cruise, Professor N. Nasu, Ocean Research Institute, University of Tokyo, for his coordination of the site survey and also to Capt. I. Tadama and the crew of the Hakuho-Maru for their cooperation. We also thank shipboard scientists Drs. H. Tokuyama and K. Fujioka, Mrs. C. Igarashi, and H. Otobe for conducting the OBS airgun operation. 

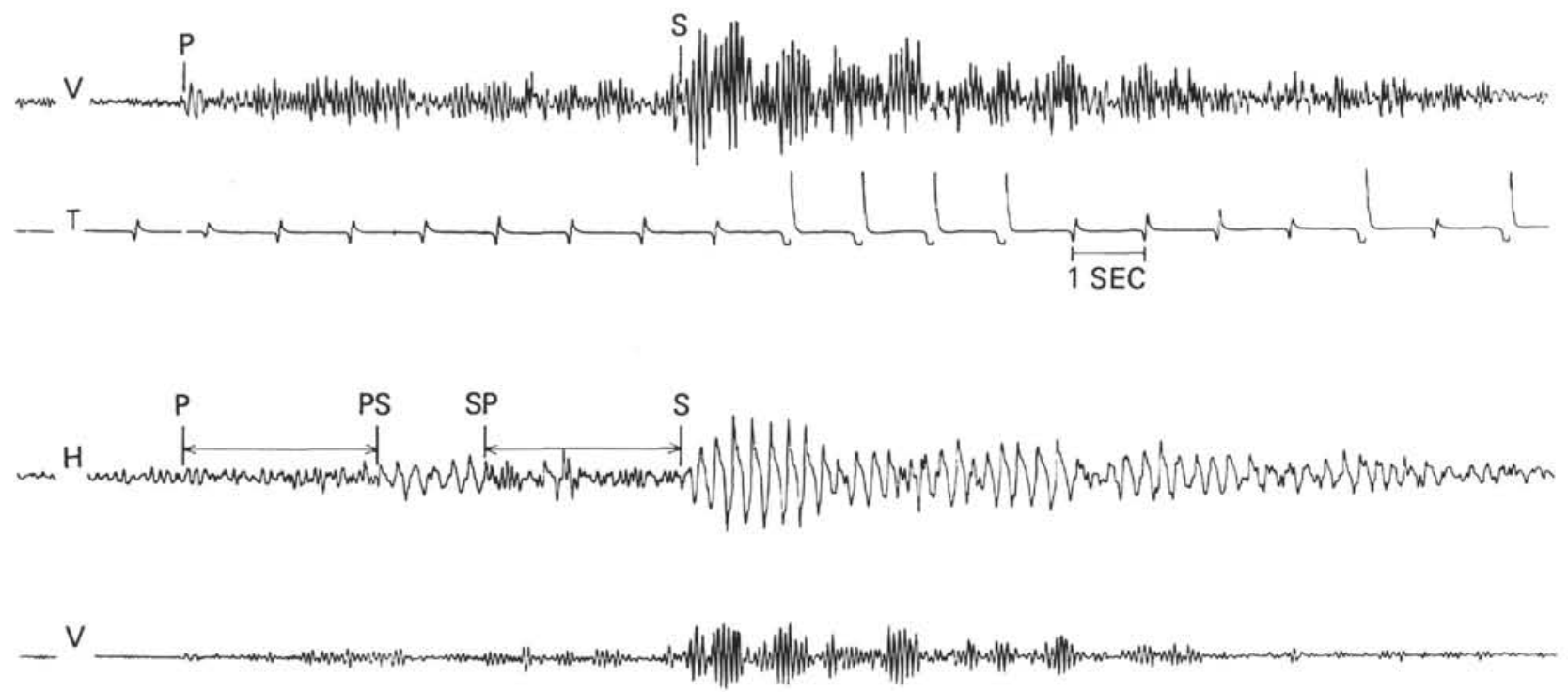

Figure 6. An example of $\mathrm{P}$ to $\mathrm{S}$ and $\mathrm{S}$ to $\mathrm{P}$ converted phases recorded by ocean bottom seismograph at Site $J-1 A$ (near Sites 441 and 434) $\mathrm{V}=$ vertical component, $\mathrm{H}=$ horizontal component, $\mathrm{T}=$ time code, $\mathrm{P}=$ arrival of $\mathrm{P}$-phases, $\mathrm{S}=$ arrival of $\mathrm{S}-$ phase, $\mathrm{PS}=$ arrival of $\mathrm{P}$ to $\mathrm{S}$ converted phase, $\mathrm{SP}=$ arrival of $\mathrm{S}$ to $\mathrm{P}$ converted phase.

\section{REFERENCES}

Houtz, R., and Ewing, J., 1976. Upper crustal structure as a function of plate age. J. Geophys. Res., 81, 2490-2498.

Matsuzawa, A., Tamano, T., Aoki, Y., and Ikawa, T., in press. Crustal structure of a subduction zone, Japan trench in northeast Japan. Mar. Geol.

Nagumo, S., and Kasahara, J., 1976. Ocean-bottom seismograph study of the western margin of the Pacific. In Sutton,
G. H., Manghnani, M. H., and Moberly, R. (Eds.), The Geophysics of the Pacific Ocean Basin and Its Margin: Am. Geophys. Union, Monogr., 19, 155-167.

Nagumo, S., Kasahara, J., and Koresawa, S., in press. Large poisson's ratio and low $S$-wave velocity within the Japan trench inner wall toe and its tectonic implication. Mar. Geol. 